ISSN 2519-2523 (print)

DOI: $10.18524 / 2519-2523.2020 .15 .218954$

УДК 2-9

\title{
ACTIVITIES OF THE “COMMISSIONER FOR THE RUSSIAN ORTHODOX CHURCH AND RELIGIOUS CULTS AT THE COUNCIL OF PEOPLE'S COMMISSARS OF THE USSR IN ODESSA" IN 1944-1965 (by materials of the State archives of Odessa region)
}

\author{
Maksym Dubna \\ ORCID: https://orcid.org/0000-0002-2661-0144 \\ Head scientific researcher \\ The State Archives of Odessa region \\ 18, Zhukovskogo str., Odessa, Ukraine, 65026 \\ maks.dubna98@gmail.com
}

The article analyzes the activities of the "Commissioner for the Russian Orthodox Church" and "Correspondence on Religious Cults" at the Council of People's Commissars of the USSR in Odessa region in 1944-1958, found unique photos from both Odessa and Odessa region destroyed, converted and rebuilt churches, chapels, houses of worship.

The mechanism of repressive pressure on worshipers and religious communities in the issue of renovation and re-registration of churches, etc. has been studied. The principle of identification and accounting of temple buildings and communities is shown.

Key words: orthodox church, religion, cult, cult buildings, commissioners, Odesa, Odesa region.

Максим Дубна

ORCID: https://orcid.org/0000-0002-2661-0144

Головний науковий співробітник

Державний архів Одеської області

вул. Жуковського, 18, Одеса, 65026, Україна

maks.dubna98@gmail.com

\section{ДІЯЛЬНІСТЬ «УПОВНОВАЖЕНОГО У СПРАВАХ РОСІЙСЬКОЇ ПРАВОСЛАВНОЇ ЦЕРКВИ ТА РЕЛІГІГІЙНИХ КУЛЬТІВ ПРИ РАДІ НАРОДНИХ КОМІСАРІВ УРСР ПО ОДЕСЬКІЙ ОБЛАСТІ В 1944-1965 РОКАХ» (за матеріалами Державного архіву Одеської області)}

У статті проаналізована діяльність «Уповноваженого у справах російської православної иеркви» та «Переписка по справах релігійних культів» при Раді Народних Комісарів УРСР по Одеській області в 1944-1958 роках», виявлені унікальні фотокартки,як одеських так й з тодішньої території Одеської області зруйнованих, перетворених $i$ перебудованих иерков, капличок, молитовних домів. Досліджений механізм репресивного тиску на служителів культу та власне релігійних громад у питанні поновлення та перереєстрачї храмів тощчо. Показаний принщии ідентифікації та обліку храмових споруд та громад.

Ключові слова: православна церква, релігія, культ, культові споруди, уповноважений, Одеса, Одеська область. 
У грудні 1965 р. в Радянському Союзі розпочинає свою діяльність Рада у справах релігій «рос. - Совет по делам религий». Вона була створена після Хрущовської антирелігійної кампанії, у результаті якої відбулося злиття двох органів підвідомчих Раді міністрів СРСР - Ради у справах Російської православної церкви (утвореної 14 вересня 1943 року) і Ради у справах релігійних культів (утвореної 19 травня 1944 року) [7, с. 414].

Справи діяльності саме цих двох органів було виокремлено з фонду Р-2000 «Одеський обласний виконавчий комітет», так би мовити фонд у фонді, а саме в описах №3 та 5 за період існування вищеописаних установ 1944-1965 рр.,виявлені наступні справи:

Уповноважений у справах Російської православної церкви

\begin{tabular}{|c|c|c|c|c|c|}
\hline $\begin{array}{c}\text { Фонд } \\
\text { № } \\
\end{array}$ & $\begin{array}{l}\text { Опис } \\
\text { № }\end{array}$ & $\begin{array}{c}\text { Спр. } \\
\text { № }\end{array}$ & $\begin{array}{c}\text { Назва справи } \\
\text { (мовою документа) }\end{array}$ & Роки & $\begin{array}{c}\text { Кількість } \\
\text { аркушів }\end{array}$ \\
\hline P-2000 & 3 & 6 & $\begin{array}{c}\text { «Уполномоченный по делам } \\
\text { православной иеркви» }\end{array}$ & $1945-1952$ & $10,16,24$ \\
\hline P-2000 & 3 & 99 & $\begin{array}{c}\text { «Переписка с православными } \\
\text { иерквями и монастырями о } \\
\text { регистрачии иерквей и др. } \\
\text { вопросам» }\end{array}$ & $\begin{array}{l}03.11 .1945- \\
10.12 .1952\end{array}$ & 135 \\
\hline P-2000 & 3 & 170 & $\begin{array}{c}\text { «Переписка с Советом } \\
\text { республиканским } \\
\text { уполномоченным и местными } \\
\text { организациями по вопросу } \\
\text { религии» }\end{array}$ & $\begin{array}{l}13.12 .1946- \\
10.12 .1952\end{array}$ & 409 \\
\hline P-2000 & 3 & 171 & $\begin{array}{c}\text { «Материаль епархиального } \\
\text { управления духовной } \\
\text { семинарии и др.» }\end{array}$ & $\begin{array}{l}21.11 .1946- \\
18.10 .1952\end{array}$ & 185 \\
\hline P-2000 & 3 & 260 & $\begin{array}{c}\text { «Переписка по русской } \\
\text { православной черкви и } \\
\text { молитвенных домов» }\end{array}$ & $\begin{array}{l}17.05 .1947- \\
17.09 .1952\end{array}$ & 148 \\
\hline P-2000 & 5 & 25 & $\begin{array}{c}\text { «ереписка по вопросам } \\
\text { русской православной черкви» }\end{array}$ & $\begin{array}{c}01.01 .1944- \\
02.06 .1944\end{array}$ & 2 \\
\hline P-2000 & 5 & 42 & $\begin{array}{c}\text { «Переписка по делам русской } \\
\text { православной церкви» }\end{array}$ & $\begin{array}{l}12.01 .1945- \\
20.12 .1945\end{array}$ & 70 \\
\hline P-2000 & 5 & 64 & $\begin{array}{c}\text { «Переписка по делам русской } \\
\text { православной церкви» }\end{array}$ & $\begin{array}{l}18.02 .1946- \\
24.01 .1947\end{array}$ & 154 \\
\hline P-2000 & 5 & 79 & $\begin{array}{c}\text { «Переписка по делам русской } \\
\text { православной церкви» }\end{array}$ & $\begin{array}{l}18.01 .1947- \\
31.12 .1947\end{array}$ & 227 \\
\hline P-2000 & 5 & 104 & $\begin{array}{c}\text { «Переписка по делам русской } \\
\text { православной церкви» }\end{array}$ & $\begin{array}{c}01.01 .1948- \\
31.12 .1948 \\
\end{array}$ & 272 \\
\hline P-2000 & 5 & 129 & $\begin{array}{c}\text { «Переписка по русской } \\
\text { православной иеркви и } \\
\text { епископе Никоне» }\end{array}$ & $\begin{array}{l}21.09 .1949- \\
30.12 .1949\end{array}$ & 57 \\
\hline P-2000 & 5 & 130 & $\begin{array}{c}\text { «Переписка по делам русской } \\
\text { православной церкви» }\end{array}$ & $\begin{array}{c}06.01 .1949- \\
31.12 .1949 \\
\end{array}$ & 164 \\
\hline P-2000 & 5 & 164 & $\begin{array}{c}\text { «Переписка по делам русской } \\
\text { православной церкви» }\end{array}$ & $\begin{array}{c}01.01 .1050- \\
30.12 .1950\end{array}$ & 136 \\
\hline
\end{tabular}




\begin{tabular}{|c|c|c|c|c|c|}
\hline P-2000 & 5 & 196 & $\begin{array}{c}\text { «Переписка по делам русской } \\
\text { православной ияеркви» }\end{array}$ & $\begin{array}{c}05.01 .1951- \\
11.12 .1951 \\
\end{array}$ & 122 \\
\hline P-2000 & 5 & 219 & $\begin{array}{c}\text { «ереписка по делам русской } \\
\text { православной ичеркви» }\end{array}$ & $\begin{array}{c}01.01 .1952- \\
30.12 .1952 \\
\end{array}$ & 192 \\
\hline P-2000 & 5 & 243 & $\begin{array}{c}\text { «Переписка по делам русской } \\
\text { православной ичеркви» }\end{array}$ & $\begin{array}{c}06.01 .1953- \\
26.12 .1953\end{array}$ & 117 \\
\hline P-2000 & 5 & 260 & $\begin{array}{c}\text { «Переписка по делам русской } \\
\text { православной иеркви» }\end{array}$ & $\begin{array}{c}05.01 .1954- \\
27.12 .1954\end{array}$ & 133 \\
\hline P-2000 & 5 & 275 & $\begin{array}{c}\text { «Переписка по делам русской } \\
\text { православной ичеркви» }\end{array}$ & $\begin{array}{c}05.01 .1955- \\
30.12 .1955 \\
\end{array}$ & 212 \\
\hline P-2000 & 5 & 289 & $\begin{array}{c}\text { «Переписка по делам русской } \\
\text { православной ичеркви» }\end{array}$ & $\begin{array}{c}09.01 .1956- \\
18.12 .1956 \\
\end{array}$ & 160 \\
\hline P-2000 & 5 & 307 & $\begin{array}{c}\text { «Переписка по делам русской } \\
\text { православной ицеркви» }\end{array}$ & $\begin{array}{c}07.01 .1957- \\
24.12 .1957 \\
\end{array}$ & 324 \\
\hline P-2000 & 5 & 331 & $\begin{array}{c}\text { «Переписка по делам русской } \\
\text { православной цееркви» }\end{array}$ & $\begin{array}{c}21.01 .1958- \\
19.12 .1958 \\
\end{array}$ & 115 \\
\hline P-2000 & 5 & 347 & $\begin{array}{c}\text { «Материаль по делам } \\
\text { русской православной } \\
\text { иеркви/Постановления } \\
\text { Совета, информацчи и др.» }\end{array}$ & $\begin{array}{c}10.01 .1959- \\
07.12 .1959\end{array}$ & 136 \\
\hline P-2000 & 5 & 365 & $\begin{array}{c}\text { «Материаль по делам } \\
\text { русской православной } \\
\text { иеркви/Постановления } \\
\text { Совета, информачии и др.» }\end{array}$ & $\begin{array}{c}12.03 .1960- \\
19.12 .1960\end{array}$ & 203 \\
\hline P-2000 & 5 & 380 & $\begin{array}{c}\text { «Материаль по делам } \\
\text { русской православной } \\
\text { иеркви/Постановления } \\
\text { Совета. информачии и др.» }\end{array}$ & $\begin{array}{c}02.01 .1961- \\
25.12 .1961\end{array}$ & 100 \\
\hline P-2000 & 5 & 396 & $\begin{array}{c}\text { «Материаль по делам } \\
\text { русской православной } \\
\text { иеркви/Постановления } \\
\text { Совета, отчеть, } \\
\text { информаччи и др.» } \\
\end{array}$ & $\begin{array}{c}08.01 .1962- \\
15.12 .1962\end{array}$ & 155 \\
\hline P-2000 & 5 & 406 & $\begin{array}{c}\text { «Материальы по делам } \\
\text { русской православной } \\
\text { церкви/сведения, информации } \\
\text { и др.» }\end{array}$ & $\begin{array}{c}01.01 .1963- \\
31.12 .1963\end{array}$ & 9 \\
\hline P-2000 & 5 & 417 & $\begin{array}{c}\text { «Материаль по делам } \\
\text { русской православной } \\
\text { иеркви/постановления } \\
\text { Совета, информаччи и др.» }\end{array}$ & $\begin{array}{c}26.06 .1963- \\
31.12 .1963\end{array}$ & 35 \\
\hline P-2000 & 5 & 428 & $\begin{array}{c}\text { «Материальы по делам } \\
\text { русской православной } \\
\text { иеркви/постановления } \\
\text { Совета, информации и др.» }\end{array}$ & $\begin{array}{c}01.01 .1963- \\
31.12 .1963\end{array}$ & 152 \\
\hline
\end{tabular}




\begin{tabular}{|c|c|c|c|c|c|}
\hline P-2000 & 5 & 438 & $\begin{array}{l}\text { Материаль по делам русской } \\
\text { православной церкви/справки, } \\
\text { сведения, информации и др.» }\end{array}$ & $\begin{array}{c}24.03 .1964-12.1964 \\
31.106\end{array}$ & 227 \\
\hline P-2000 & 5 & 448 & $\begin{array}{l}\text { Материаль по делам русской } \\
\text { православной церкви/отчеть, } \\
\text { сведения, информачии и др.» }\end{array}$ & $\begin{array}{c}09.01 .1965- \\
31.12 .1965\end{array}$ & \\
\hline
\end{tabular}

Уповноважений у справах релігійних культів

\begin{tabular}{|c|c|c|c|c|c|}
\hline $\begin{array}{l}\text { Фонд } \\
\text { № }\end{array}$ & $\begin{array}{c}\text { Опис } \\
\text { № }\end{array}$ & $\begin{array}{c}\text { Спр. } \\
\text { № }\end{array}$ & $\begin{array}{c}\text { Назва справи } \\
\text { (мовою документа) }\end{array}$ & Роки & $\begin{array}{l}\text { Кількість } \\
\text { аркушів }\end{array}$ \\
\hline P-2000 & 3 & 7 & $\begin{array}{l}\text { «Уолномоченный по делам } \\
\text { религиозных культов» }\end{array}$ & $1945-1956$ & $\begin{array}{l}10,17,24,31, \\
38,78,88 .\end{array}$ \\
\hline P-2000 & 3 & 100 & $\begin{array}{l}\text { «Переписка по делам } \\
\text { религиозных культов» }\end{array}$ & $\begin{array}{c}06.07 .1945- \\
06.09 .1946\end{array}$ & - \\
\hline P-2000 & 3 & 172 & $\begin{array}{c}\text { «Переписка по вопросам } \\
\text { религиозныхх культов с Советом } \\
\text { по делам религиозных культов } \\
\text { при Совете Министров СССР» }\end{array}$ & $\begin{array}{l}12.01 .1946- \\
11.12 .1947\end{array}$ & 50 \\
\hline P-2000 & 3 & 173 & $\begin{array}{c}\text { «Переписка о религиозной } \\
\text { общине Молокан» }\end{array}$ & $\begin{array}{c}20.06 .1946- \\
18.12 .1946 \\
\end{array}$ & 17 \\
\hline P-2000 & 3 & 174 & $\begin{array}{c}\text { «Религиозные общества снятые } \\
\text { с регистрации» }\end{array}$ & $\begin{array}{l}16.02 .1946- \\
26.11 .1952 \\
\end{array}$ & 139 \\
\hline P-2000 & 3 & 175 & «тоже» & $\begin{array}{c}01.05 .1946- \\
01.03 .1956\end{array}$ & 39 \\
\hline P-2000 & 3 & 176 & «тоже» & $\begin{array}{c}09.08 .1946- \\
07.08 .1950\end{array}$ & 236 \\
\hline P-2000 & 3 & 177 & 《тоже» & $\begin{array}{c}15.10 .1946- \\
17.11 .1948\end{array}$ & 105 \\
\hline P-2000 & 3 & 178 & «тоже» & $\begin{array}{l}01.06 .1946- \\
20.10 .1951\end{array}$ & 124 \\
\hline P-2000 & 3 & 261 & $\begin{array}{l}\text { «Переписка по вопросам } \\
\text { религиозных культов» }\end{array}$ & $\begin{array}{c}09.01 .1947- \\
17.09 .1947\end{array}$ & 51 \\
\hline P-2000 & 3 & 343 & $\begin{array}{l}\text { «Переписка по вопросам } \\
\text { религиозных культов» }\end{array}$ & $\begin{array}{c}10.01 .1948- \\
13.07 .1948\end{array}$ & 45 \\
\hline P-2000 & 3 & 344 & «тоже» & $\begin{array}{c}10.02 .1948- \\
16.02 .1948\end{array}$ & 46 \\
\hline P-2000 & 3 & 345 & 《mоже» & $\begin{array}{c}20.01 .1948- \\
20.11 .1948\end{array}$ & 88 \\
\hline P-2000 & 3 & 462 & $\begin{array}{c}\text { «полномоченный по } \\
\text { религиозным культам } u \\
\text { религиозные общества снятые с } \\
\text { регистрачии» }\end{array}$ & $\begin{array}{c}21.05 .1949- \\
02.11 .1949\end{array}$ & 172 \\
\hline P-2000 & 3 & 1087 & $\begin{array}{c}\text { «Переписка о религиозных } \\
\text { культах и религиозные } \\
\text { общества, которым отказано в } \\
\text { регистраиии» }\end{array}$ & $\begin{array}{c}23.11 .1953- \\
06.12 .1956\end{array}$ & 148 \\
\hline P-2000 & 3 & 1219 & $\begin{array}{c}\text { «кты сдачи дел религиозных } \\
\text { обществ перешедиих в }\end{array}$ & $\begin{array}{c}30.06 .1954- \\
06.07 .1954\end{array}$ & 5 \\
\hline
\end{tabular}




\begin{tabular}{|c|c|c|c|c|c|}
\hline & & & $\begin{array}{c}\text { Николаевскую } и \\
\text { Кировоградскую области» }\end{array}$ & & \\
\hline P-2000 & 5 & 43 & $\begin{array}{c}\text { «Переписка по делам } \\
\text { религиозных культов» }\end{array}$ & $\begin{array}{l}07.01 .1945- \\
31.12 .1945\end{array}$ & 53 \\
\hline P-2000 & 5 & 55 & $\begin{array}{c}\text { «Переписка по вопросам } \\
\text { религиозных культов» }\end{array}$ & $\begin{array}{c}07.01 .1946- \\
13.12 .1946\end{array}$ & 90 \\
\hline P-2000 & 5 & 80 & $\begin{array}{c}\text { «Переписка по делам } \\
\text { религиозных культов» }\end{array}$ & $\begin{array}{l}26.12 .1946- \\
25.11 .1947\end{array}$ & 121 \\
\hline P-2000 & 5 & 103 & $\begin{array}{l}\text { «Переписка по делам } \\
\text { религиозных культов» }\end{array}$ & $\begin{array}{c}01.02 .1948- \\
31.12 .1948\end{array}$ & 165 \\
\hline P-2000 & 5 & 128 & $\begin{array}{l}\text { «Переписка по делам } \\
\text { религиозныхх культов» }\end{array}$ & $\begin{array}{c}06.01 .1949- \\
31.12 .1949\end{array}$ & 159 \\
\hline P-2000 & 5 & 163 & $\begin{array}{l}\text { «Переписка по делам } \\
\text { религиозных культов» }\end{array}$ & $\begin{array}{c}01.01 .1950- \\
30.12 .1950\end{array}$ & 143 \\
\hline P-2000 & 5 & 195 & $\begin{array}{l}\text { «Переписка по делам } \\
\text { религиозных культов» }\end{array}$ & $\begin{array}{c}08.01 .1951- \\
29.12 .1951\end{array}$ & 133 \\
\hline P-2000 & 5 & 218 & $\begin{array}{l}\text { «Переписка по делам } \\
\text { религиозных культов» }\end{array}$ & $\begin{array}{c}12.01 .1952- \\
23.12 .1952 \\
\end{array}$ & 184 \\
\hline P-2000 & 5 & 242 & $\begin{array}{l}\text { «Переписка по делам } \\
\text { религиозныхх культов» }\end{array}$ & $\begin{array}{c}06.01 .1953- \\
16.12 .1953\end{array}$ & 113 \\
\hline P-2000 & 5 & 259 & $\begin{array}{c}\text { «Переписка по делам } \\
\text { религиозных культов» }\end{array}$ & $\begin{array}{c}19.01 .1954- \\
30.12 .1954 \\
\end{array}$ & 71 \\
\hline P-2000 & 5 & 276 & $\begin{array}{l}\text { «Переписка по делам } \\
\text { религиозных культов» }\end{array}$ & $\begin{array}{l}05.01 .1955- \\
28.12 .1955\end{array}$ & 202 \\
\hline P-2000 & 5 & 288 & $\begin{array}{c}\text { «Переписка по делам } \\
\text { религиозных культов» }\end{array}$ & $\begin{array}{c}02.01 .1956- \\
29.12 .1956 \\
\end{array}$ & 278 \\
\hline P-2000 & 5 & 306 & $\begin{array}{l}\text { «Переписка по делам } \\
\text { религиозных культов» }\end{array}$ & $\begin{array}{c}02.01 .1957- \\
31.12 .1957 \\
\end{array}$ & 292 \\
\hline P-2000 & 5 & 330 & $\begin{array}{c}\text { «Переписка по делам } \\
\text { религиозных культов» }\end{array}$ & $\begin{array}{c}11.01 .1958- \\
16.12 .1958\end{array}$ & 194 \\
\hline P-2000 & 5 & 348 & $\begin{array}{c}\text { «Материаль по делам рели- } \\
\text { гиозных культов/ постановле- } \\
\text { ния Совета, информацчи и др./» }\end{array}$ & $\begin{array}{c}06.01 .1959- \\
20.12 .1959\end{array}$ & 199 \\
\hline P-2000 & 5 & 364 & $\begin{array}{c}\text { «Материаль по делам рели- } \\
\text { гиозныхх культов/постановления } \\
\text { Совета, информации и др./» }\end{array}$ & $\begin{array}{c}09.01 .1960- \\
27.12 .1960\end{array}$ & 163 \\
\hline P-2000 & 5 & 381 & $\begin{array}{c}\text { «Материаль по делам рели- } \\
\text { гиозных культов/постановления } \\
\text { Совета, информацчи и др./» }\end{array}$ & $\begin{array}{c}02.01 .1961- \\
04.09 .1961\end{array}$ & 274 \\
\hline P-2000 & 5 & 382 & $\begin{array}{c}\text { «Материаль по делам рели- } \\
\text { гиозныхх культов/постановления } \\
\text { Совета, информации и др./» }\end{array}$ & $\begin{array}{c}06.09 .1961- \\
25.12 .1961\end{array}$ & 156 \\
\hline P-2000 & 5 & 397 & $\begin{array}{c}\text { «Материальы по делам религио- } \\
\text { зныхх культов/постановления } \\
\text { Совета, отчеты, информации и } \\
\text { др./» }\end{array}$ & $\begin{array}{c}03.01 .1962- \\
06.10 .1962\end{array}$ & 175 \\
\hline P-2000 & 5 & 407 & $\begin{array}{c}\text { «Материаль по делам } \\
\text { религиозных культов/сведения, } \\
\text { информации и др./» }\end{array}$ & $\begin{array}{c}01.01 .1963- \\
31.12 .1963\end{array}$ & 57 \\
\hline
\end{tabular}




\begin{tabular}{|c|c|c|c|c|c|}
\hline P-2000 & 5 & 418 & $\begin{array}{c}\text { «Материальы по делам религиоз- } \\
\text { нырх культов/планьl, отчеты, } \\
\text { информации, переписка/» }\end{array}$ & $\begin{array}{c}04.02 .1963- \\
26.12 .1963\end{array}$ & 150 \\
\hline P-2000 & 5 & 429 & $\begin{array}{c}\text { «Материаль по делам религиоз- } \\
\text { ных культов/постановления } \\
\text { Совета, информации и др./» }\end{array}$ & $\begin{array}{c}01.01 .1963- \\
31.12 .1963\end{array}$ & 89 \\
\hline P-2000 & 5 & 439 & $\begin{array}{c}\text { «Материальы по делам религиоз- } \\
\text { ных культов/ планы, отчеты, } \\
\text { информации, докладные } \\
\text { записки, переписка/» }\end{array}$ & $\begin{array}{c}07.01 .1964- \\
31.12 .1964\end{array}$ & 233 \\
\hline P-2000 & 5 & 449 & $\begin{array}{c}\text { «Материаль по делам религиоз- } \\
\text { ных культов/ отчеты, сведения, } \\
\text { информачии и др.» }\end{array}$ & $\begin{array}{c}22.01 .1965- \\
11.10 .1965\end{array}$ & 327 \\
\hline
\end{tabular}

Загалом 70 справ, із них 30 - «Уповноваженого у справах Російської православної церкви» та 40 - «у справах релігійних культів» $[1,2]$.

У ф. Р-2000, оп. 3, спр. 170 містяться унікальні відомості та фотографії церков, храмів, молитовних домів, капличок як м. Одеса, так і тодішньої Одеської області. Уповноважений Ради по Одеській області пише висновок до Виконкому Одеської Облради депутатів трудящих:

Документ №1. Лист-ухвала Виконавчому комітету Одеськой обласноӥ ради депутатів трудящих. 2 жсовтня 1950 р., Одеса.

«ИСПОЛНИТЕЛЬНОМУ КОМИТЕТУ ОДЕССКОГО ОБЛАСТНОГО СОВЕТА ДЕПУТАТОВ ТРУДЯЩИХСЯ

По вопросу снесения часовни, построенной в период

немеикой оккупачии, на Октябрьском рынке,

Кагановичского района, города Одессы

\section{ЗАКЛЮЧЕНИЕ}

Исполнительный комитет Кагановичского района, города Одессы, в связи с проводимой реконструкиией Октябрьского рынка, ходатайствует о сносе часовни, находящейся на площади Октябовского рынка.

Учитывая, что часовня, построенная в период немецкой оккупации, находится в центре площади привокзального Октябрьского рынка. В этой часовне, до середины 1947 года производилось служение молебнов, продажа свечной, крестиков и других церковных предметов, иеромонахом Ионикием, постоянно прикрепленным к этой часовне, из числа братии быв. Пантелеймоновского мужского монастыря.

В начале 1948 года, по моему совету, деятельность монастыря в этой часовне была прекращена Архиепископом Фотием. Часовня же, осталась на месте, является же совершенно не нужным сооружением среди торговых помещений государственных и кооперативных организаций торгующих на базаре.

Считаю возможным, удовлетворить просьбу Кагановичского Исполклма Райсовета депутатов трудящихся о снесении часовни, находящейся на площуади привокзального Октябрьского рынка города Одессы.

Уполномоченный Совета

По Одесской области /Благов/

«2» октября 1950 г.

2. Oдесса»

Державний архів Одеської області. Ф. Р-2000. Оп.3. Спр.170. Арк.196. 
Документ №2. Зображення часовні. Одеса.

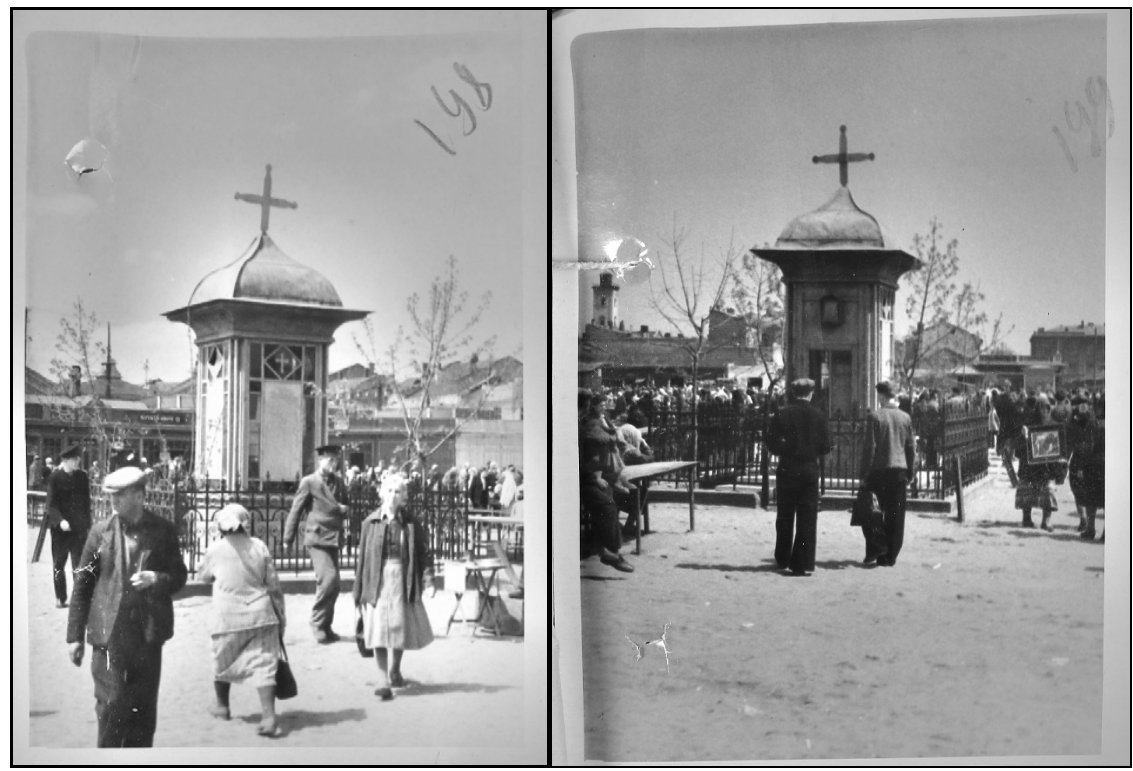

Державний архів Одеської області. Ф. Р-2000. Оп.3. Спр.170. Арк.198-199.

Документ №3. Рімення Виконавчого Кагановицького райради депутатів трудящих. 26 серпня 1950 р., Одеса.

«РЕШЕНИЕ

Исполнителкома Кагановичского Райсовета депутатов трудящихся

26-го августа 1950 2. №468 гор. Одесса

О закрытии часовни православной иеркви, находящейся на Октябрьском рынке.

В связи с реконструкцией Октябрьского рынка, для улучшения обслуживания трудящихся,- Исполком Кагановичского Райсовета депутатов трудящихся РЕШИЛ:

1. Снести часовню православной церкви с площчади Октябрьского рынка, освободив место для постройки павильонов.

2. Просить Исполком Горсовета утвердить настоящее решение.

и. о. Пред. Исполкома Кагановичского

Райсовета депутатов трудящихся

/П. СЕДЛЯРЕВИЧ/

Секретарь Исполкома Райсовета

депутатов трудящихся

/А. СПИЦИНА/»

Державний архів Одеської області. Ф. Р-2000. On.3. Спр.170. Арк.197. 
Документ №4. Рішення Виконавчого комітета Одеської обласної Ради депутатів трудящих. 13 жовтня 1950 р., Одеса.

«РЕШЕНИЕ

Исполнительного Комитета Одесского Областного Совета

Депутатов трудящихся

2. Одесса №1906/1 «13» октября 1950 года.

О снесении часовни, находящейся на привокзальной площади Октябрьского рынка, города Оессы.

Учитывая просьбу Исполнителльного Комитета Кагановичского Райсовета депутатов трудящихся г. Одессы и неуместное нахождение часовни на площади Октябрьского рынка г. Одессы, - Исполнительный Комитет Одесского Областного Совета Депутатов трудящихся РЕШИЛ:

Согласиться с заключением уполномоченного Совета по делам русской православной иееркви при Совете Министров СССР по Одесской области о снесении часовни, построенной в период немецкой оккупации, на привокзальной площади Октябрьского рынка, в Кагановичском районе, города Одессы.

Предиедатель Исполкома Обласовета

Депутатов трудящихся

/K. KAPABAEB/

Секретарь Исполкома Обласовета

Депутатов трудящихся

/И. НИКИФОРОВ/»

Державний архів Одеської області. Ф. Р-2000. Оп.3. Спр.170. Арк.195.

Справи діяльності «Уповноваженого у справах Російської православної церкви» та «Уповноваженого у справах релігійнихкультів» містять унікальні документи та матеріали які стосуються релігійного життя людей та долі культових споруд Одеського регіону в 1944-1965 pp.

\section{Джерела та літератури:}

1. Державний архів Одеської області. - Ф. Р - 2000. - Оп.3. - Спр. 170. - 162 арк.

2. Державний архів Одеської області. - Ф. Р - 2000. - Оп. 5. - 29 арк.

3. Совет по делам религий при Совете министров СССР // Атеистический словарь / под ред. М. П. Новикова. - Москва: Политиздат, 1985. - С. 414.

\section{References:}

1. Derzhavnyy arkhiv Odes'koyi oblasti (The State archives of Odessa region (Ukraine)). F. R. 2000. Op. 3. Spr. 170. 162 ark.

2. Derzhavnyy arkhiv Odes'koyi oblasti (The State archives of Odessa region (Ukraine)). F. R. 2000. Op. 5. 29 ark.

3. Sovet po delam religiy pri Sovete ministrov SSSR. In: Novikova, M. P. red, 1985. Ateisticheskiy slovar'. Moskva: Politizdat. p. 414.

Отримано: 05.12.2019 p. 